\title{
PERAN SERTA MASYARAKAT KELURAHAN KARANG BALIKPAPAN UTARA DALAM USAHA-USAHA PENCEGAHAN KEBAKARAN HUTAN DAN LAHAN
}

\author{
Ismail Bakrie $^{1}$, Herodeni Setiawan ${ }^{2}$, dan Zikri Azham ${ }^{2}$ \\ ${ }^{1}$ Kehutanan, Fakultas Pertanian, Universitas 17 Agustus 1945 Samarinda, Indonesia. \\ ${ }^{2}$ Dosen Fakultas Pertanian, Universitas 17 Agustus 1945 Samarinda 75124, Indonesia. \\ E-Mail: bakrieis@gmail.com
}

\begin{abstract}
ABSTRAK
Peran Serta Masyarakat Kelurahan Karang Balikpapan Utara Dalam Usaha-Usaha Pencegahan Kebakaran Hutan Dan Lahan. Berdasarkan masalah-masalah yang ditemukan dilapangan dan analisis/pembahasan masalah yang terkait dengan tujuan penelitian maka diperoleh hasi bahwa sistem penanggulangan kebakaran hutan berbasis masyarakat telah dilaksanakan secara turun temurun oleh masyarakat dengan menggunakan teknik dan peralatan tradisional. Dalam penyiapan lahan untuk kebun, masyarakat lokal masih melakukan pembakaran, dan selalu membuat sekat bakar berupa rintisan-rintisan di sekeliling areal yang akan dibakar serta melakukan pengawasan pada saat membakar berlangsung untuk menghindari perluasan api.

Strategi dalam penanggulangan kebakaran hutan dan lahan berbasis masyarakat adalah peningkatan taraf pendidikan masyarakat, meminimalkan sistem perladangan berpindah (gilir balik) dengan pola tebas bakar dan mencari sumber dana secara mandiri untuk meminimalkan terjadinya bahaya kebakaran yang pada gilirannya akan menambah luasnya lahan kritis, selain itu menghindari terjadinya konflik kepemilikan lahan, dan juga perlunya keterbatasan tenaga pendamping yang berpengalaman.

Rancangan alternatif dalam pengembangan sistem PKHBM adalah upaya-upaya pencegahan dan penanggulangan secara teknis, penerapan pola tanam terpadu, pendekatan partisipatif dalam penyusunan program PKHBM, serta pembentukan usaha kelompok bersama (UKB) dan pendampingan intensif.
\end{abstract}

Kata kunci : Kebakaran, hutan, lahan.

\begin{abstract}
The Role Of The Coral And North Balikpapan Kelurahan Community In Forest And Land Fire Prevention. Based on the problems found in the field and analysis/discussion of problems related to the research objectives, it was found that the community-based forest fire control system has been implemented for generations by the community using traditional techniques and equipment. In preparing land for plantations, local people still burn, and always make firebreaks in the form of stubs around the area to be burned and supervise when burning takes place to avoid expanding fires.

The strategy in handling community-based forest and land fires is to increase the level of education on community, minimize shifting cultivation systems by shifting slash-and-burn patterns and seek sources of funding independently to minimize the occurrence of fire hazards which in turn will increase the extent of critical land, while avoiding land ownership conflicts occur, and also the need for experienced facilitators.

Alternative ideas in developing the PKHBM system are technical prevention and mitigation efforts, the application of integrated cropping patterns, participatory approaches in the preparation of the PKHBM program, as well as the formation of joint group businesses (UKB) and intensive assistance.
\end{abstract}

Key words : Fire, forest, land.

\section{PENDAHULUAN}

Kalimantan Timur merupakan salah satu Provinsi di Indonesia yang telah beberapa kali mengalami kebakaran hutan dan lahan yang besar, antara lain pada tahun 1982/1983 yang memusnahkan sekitar 3,2 juta hektar 
hutan, kebakaran besar di berbagai kawasan hutan dan lahan terus terjadi berulang-ulang 1987, 1991 dan 1994. Kebakaran lebih besar terjadi lagi pada tahun 1997/1998 yang membakar sekitar 5,2 juta hektar kawasan hutan dan lahan (Hoffman dkk, 1999).

Berbagai upaya pemerintah dalam menanggulangi kebakaran hutan dan lahan telah dilakukan, baik untuk kawasan hutan produksi (HPH/HPHTI), kawasan hutan konservasi atau kawasan lindung dan juga untuk lahan masyarakat di dalam maupun sekitar hutan. Pembentukan regu-regu pemadam jagawana dan juga regu-regu pemadam masyarakat merupakan upaya penyiapan sumber daya manusia yang diharapkan dapat membantu dalam pengendalian kebakaran hutan dan lahan (Anonim, 2002).

Perhatian pemerintah maupun lembaga non pemerintah (LSM maupun Lembaga Donor Luar Negeri) dalam dukungan mengurangi tingkat bahaya kebakaran hutan dan lahan di kawasan pemukiman masyarakat di dalam maupun di sekitar hutan berupa insentif. Insentif dimaksudkan memberikan sesuatu kepada masyarakat dalam memotivasi aktivitas masyarakat. Insentif yang diberikan berupa fisik dan non fisik. Insentif fisik berupa bantuan peralatan, bantuan dana untuk organisasi pemadam, bantuan bibit dan lain-lain. Insentif non fisik berupa pelatihan/ penyegaran, penyuluhan dan kampanye, penghargaan dan lain-lain (Anonim, 2002).

Bagaimana hasil sosialisasi, penyuluhan-penyuluhan yang telah dilakukan dan berbagai upaya pemerintah seperti pembentukan regu-regu pemadam kebakaran dan pemberian berbagai bentuk insentif, khususnya di daerah Kelurahan Karang Joang Balikpapan Utara dan sekitarnya, sampai saat ini belum diketahui, apakah telah mencapai hasil yang diinginkan. Diharapkan dari upaya-upaya yang telah dilakukan ini dapat tercapai suatu hasil yang konstruktif, yaitu tercapainya proses pencapaian tujuan, yakni adanya kemandirian dari suatu sistem pengelolaan kebakaran hutan dan lahan. Untuk mengetahui tingkat respon dan tanggapan masyarakat terhadap berbagai usaha-usaha pembinaan dalam kegiatan pencegahan kebakaran hutan, maka perlu dilakukan evaluasi dan telaah yang menyeluruh.

Dari uraian-uraian tersebut di atas, untuk mengetahui respon masyarakat terhadap usaha-usaha pencegahan kebakaran hutan dan lahan, maka penulis bermaksud mengadakan penelitian dengan judul "Respon Masyarakat Kelurahan Karang Joang Terhadap Usaha-Usaha Pencegahan Kebakaran Hutan dan Lahan. Tujuan penelitian adalah Untuk mengetahui sikap masyarakat terhadap cara-cara kegiatan pembukaan atau penyiapan lahan tanam yang selama ini terjadi dimasyarakat. Untuk mengetahui sebab-sebab terjadinya kebakaran hutan dan lahan yang diketahui oleh masyarakat sebagai penyebab paling dominan terjadinya kebakaran hutan dan lahan. Mengetahui respon masyarakat terhadap kegiatan sosialisasi atau pembinaan pemerintah dalam memasyarakatkan upaya-upaya pelibatan masyarakat dalam kegiatan pencegahan kebakaran hutan dan lahan.

\section{METODA PENELITIAN}

\subsection{Tempat dan Waktu}

Penelitian dilaksanakan di Kelurahan Karang Joang Kota Balikpapan, Provinsi Kalimantan Timur. Pada bulan April-Mei 2012.

\subsection{Objek Penelitian}

Objek penelitian ini adalah masyarakat yang berada di wilayah Kelurahan Karang Joang, tokoh-tokoh masyarakat, Camat dan Lurah/Kepala 
Desa. Aspek-aspek yang menjadi objek penelitian adalah aspek budaya, aspek sosial dan aspek ekonomi dalam pengembangan sistem pengelolaan kebakaran hutan dan lahan di tingkat masyarakat, khususnya di daerah rawan kebakaran hutan dan lahan.

\subsection{Bahan dan Alat Penelitian}

Bahan dan peralatan yang digunakan dalam penelitian ini yaitu : Kuisioner (angket), sebagai media pertanyaan untuk memperoleh informasi, Kamera, untuk mendokumentasikan objek penelitian, Kalkulator dan alat tulis menulis, untuk pengumpulan dan pengolahan data, Data dokumentasi yang diperlukan berkaitan dengan lokasi penelitian meliputi : Peta lokasi penelitian, Data kebakaran hutan dan lahan di Kelurahan Karang Joang Kecamatan Balikpapan Utara Tahun 2005-2010, Data kegiatan pengendalian kebakaran hutan dan lahan di Kelurahan Karang Joang Kecamatan Balikpapan Utara Tahun 2005-2010, Data distribusi peralatan manual kebakaran hutan dan lahan di Kelurahan Karang Joang Kecamatan Balikpapan Utara, Bentuk-bentuk organisasi pencegahan/pemadaman kebakaran hutan dan lahan yang ada di Kelurahan Karang Joang Kecamatan Balikpapan Utara, Kalender Musim dan Sketsa Potensi Desa.

\subsection{Metode Penelitian}

Dalam penelitian ini metode yang digunakan adalah metode survei dengan teknik pengumpulan data menggunakan Purposive Sampling, dimana tidak semua individu dalam populasi diteliti namun diharapkan dapat menggambarkan populasi yang bersangkutan (Anonim, 1996 dalam
Tambunan, 2003) dan (Singarimbun, 1989).

Alat pengumpulan data menggunakan kuisioner, dan selama pengumpulan data dan informasi, peneliti sesekali tinggal bersama penduduk dan mengamati aktivitas yang dilakukan oleh mereka. Pengamatan juga dilakukan terhadap hal-hal yang berkaitan dengan data atau informasi yang diharapkan.

\subsubsection{Metode Penelitian dan Teknik} Penentuan Sampel

Metode yang digunakan dalam penelitian ini adalah Metode Survei, dan sebagai obyek survei dalam penelitian adalah desa dimana masyarakatnya terlibat dalam penanggulangan kebakaran hutan dan lahan. Teknik pemilihan dan penentuan sampel yang digunakan adalah purposive sampling yaitu pengambilan contoh secara sederhana dengan mengambil sampel dari populasi yang ada kaitannya (mempunyai kesamaan ciri-ciri tertentu dan terarah) sesuai dengan tujuan penelitian (Anonim, 1996 dalam Tambunan, 2003). Sesuai intensitas sampling atau proporsi jumlah responden yang diambil sebagai sampel dalam penelitian ini, maka telah didata sebanyak 50 orang responden dari masyarakat yang berada di wilayah Kelurahan Karang Joang. Untuk mendapatkan data yang representatif dari populasi masyarakat Kelurahan Karang Joang, maka pengambilan sampel dilakukan kurang lebih merata/menyebar di seluruh wilayah kelurahan. Selanjutnya untuk mendapat data yang akurat, dalam penelitian ini digunakan informan dari aparat instansi yang terkait, tokoh masyarakat, individu-individu yang 
mengetahui, lembaga-lembaga yang relevan dan lain-lain.

\subsubsection{Pengumpulan Data}

Pengumpulan data dalam penelitian ini dilaksanakan melalui teknik pengumpulan data primer dengan menggunakan kuisioner, wawancara, observasi lapangan. Pengumpulan data sekunder melalui studi dokumentasi berupa data statistik kelurahan, laporan-laporan instansi terkait, dan hasil penelitian terdahulu. Selanjutnya dilakukan analisis secara deskriptif untuk memberikan gambaran mengenai kondisi dari objek yang diteliti.

Pengumpulan data primer adalah sebagai berikut : Orientasi lapangan dengan maksud untuk memperoleh gambaran yang lebih tepat mengenai areal penelitian sehingga diperoleh informasi dan data akurat. Pemilihan responden dilakukan sesuai metode purposive sampling dari seluruh warga Kelurahan Karang Joang yang diperkirakan terlibat kegiatan pencegahan kabakaran hutan dan lahan. Mendatangi kepala-kepala keluarga yang terpilih untuk diwawancarai dan mengisi kuisioner yang telah disiapkan. Mengumpulkan data melalui wawancara dan kuisioner dari Camat dan Lurah serta tokoh masyarakat yang terkait dengan upaya-upaya pencegahan/pemadam kebakaran hutan dan lahan.

\subsection{Pengolahan Data}

Secara umum data hasil penelitian yang dikumpulkan melalui kuisioner dan observasi/pengamatan langsung di lapangan dipilih dan ditabulasikan berdasarkan kelompok data yang diperlukan untuk menjawab berbagai permasalahan yang ingin diketahui. Data tersebut kemudian dianalisis secara deskriptif kualitatif dan deskriptif kuantitatif. Dari hasil pengolahan data tersebut akan dapat disusun suatu kesimpulan dan penyampaian saran-saran sebagai hasil akhir dari penelitian ini.

\section{HASIL PENELITIAN DAN PEMBAHASAN}

\subsection{Gambaran Umum Lokasi Penelitian Letak Penelitian}

Kelurahan Karang Joang terletak di wilayah administrasi pemerintahan Kecamatan Balikpapan Utara Kota Balikpapan . Secara administrasi kehutanan termasuk di wilayah UPTD Pengendalian Pengelolaan Hasil Hutan Wilayah Selatan. Aksesibiltas menuju Kelurahan Karang Joang dapat ditempuh melalui jalan darat / jalan provinsi dari Samarinda menuju Balikpapan sekitar $90 \mathrm{~km}$ atau $2 \mathrm{Jam}$ perjalanan darat.

Sebagian masyarakat Kelurahan Karang Joang berada di dalam kawasan Hutan Lindung Sungai Wain dan di luar kawasan Hutan Lindung Sugai Wain.

Tanah dan Topografi

Secara umum topografi di lokasi penelitian mempunyai topografi dengan kemiringan antara 10-30 \%, dan ada beberapa yang mempunyai kemiringan sampai dengan $40 \%$ lebih. Ketinggian dari permukaan laut sampai dengan $240 \mathrm{~m}$ dari permukaan laut.

Secara umum tanah yang terdapat di daerah ini berasal dari batuan induk vulkanis, tetapi didomisili oleh tanah-tanah acrisol yang miskin hara dengan tekstur tanah lempung berpasir.

Keadaan Masyarakat Kelurahan Karang Joang

Masyarakat yang tinggal di Kelurahan Karang Joang pada umumnya mata pencaharian mereka yaitu bertani atau berladang dan sebagian ada yang bekerja swasta. Mayoritas masyarakat yang tinggal di Kelurahan Karang Joang beragama Islam.

Sejarah Kebakaran Hutan 
Kebakaran hutan semula dianggap terjadi secara alami, tetapi kemungkinan manusia mempunyai peran dalam memulai kebakaran, pertama untuk memudahkan perburuan dan selanjutnya untuk membuka petak-petak pertanian di dalam hutan. Meskipun kebakaran telah menjadi suatu ciri hutan-hutan di Indonesia selama beribu-ribu tahun, kebakaran yang terjadi mula-mula pasti lebih kecil dan lebih tersebar dari segi frekuensi dan waktunya dibandingkan dua dekade belakangan ini. Oleh karena itu, kebakaran yang terjadi mula-mula ini bukan merupakan penyebab deforestasi yang signifikan.

Hal ini terlihat jelas dari kenyataan bahwa sebagian besar wilayah Kalimantan Timur adalah hutan, dan baru pada waktu belakangan ini mengalami deforestasi yang sangat tinggi. Berbagai proses degradasi hutan dan deforestasi mengubah kawasan hutan yang luas di Indonesia dari suatu ekosistem yang tahan kebakaran menjadi ekosistem yang rentan terhadap kebakaran. Secara periodik pada tahun 1980 dan 1990-an, kebakaran berarti terjadi di kawasan ini. Tetapi para ahli setuju bahwa kebakaran yang terjadi selama tahun 1997-1998 merupakan peristiwa yang paling menimbulkan kerusakan disebabkan musim kering panjang, yang katanya akibat fenomena arus balik El Nino yang bertepatan pula dengan peristiwa perluasan pembukaan lahan untuk hutan tanaman.

Kebakaran Tahun 1982-1983 merupakan kebakaran hebat pertama yang merupakan akibat gabungan antara pengelolaan hutan di era Soeharto dan fenomena iklim El Niño menghancurkan $210.000 \mathrm{~km} 2$ dari wilayah Propinsi Kalimantan Timur. Kalimantan Timur merupakan fokus pertama ledakan produksi kayu Indonesia, dan hampir seluruh kawasan dibagi menjadi kawasan HPH selama tahun 1970-an. Praktek kegiatan pembalakan di sini umumnya buruk, meninggalkan akumulasi limbah pembalakan yang luar biasa di dalam hutan.

Banyak spesies pionir dan sekunder tumbuh pesat di kawasan-kawasan yang telah dibalak, sehingga membentuk lapisan vegetasi bawah yang padat dan mudah terbakar. Pembakaran lahan-lahan padang rumput dan semak belukar secara sengaja menyebabkan api merembet masuk ke perbatasan hutan yang dibalak yang terbakar dengan intensitas yang lebih besar. Kebakaran akhirnya mencapai rawa gambut yang kering, dimana api terbakar di bawah permukaan lama setelah pasokan bahan bakar di permukaan menjadi habis.

Kondisi alam di daerah Kelurahan Karang Joang yang kering pada saat musim kemarau panjang sangat berpotensi sebagai daerah yang sangat rawan akan bahaya kebakaran, apalagi daerah yang berada dekat Kawasan Hutan Lindung Sungai Wain. Pembakaran yang dilakukan masyarakat setempat dalam penyiapan lahan terus dilakukan sampai sekarang dalam penyiapan lahan untuk berladang (padi, lada dan tanaman buahbuahan). Penyebab awal kebakaran biasanya disebabkan oleh faktor manusia, yaitu membuang puntung rokok sembarangan dan kelalaian pada saat berladang. Penyiapan lahan dengan membakar, dan juga aktivitas lain seperti memasak atau menyalakan api unggun pada saat mulai penanaman, biasanya masyarakat (petani lada) membuat pondok kerja di sekitar areal kebun lada tersebut.

\subsection{Hasil Wawancara dan Penyebaran Kuisioner \\ Sesuai metode penelitian, pada} penelitian ini penulis melakukan wawancara langsung kepada 50 responden masyarakat yang berada di wilayah Kelurahan Karang Joang untuk dapat memberikan jawaban atau mengisi kuisoner mengenai usaha-usaha 
pencegahan dalam kebakaran hutan dan lahan, baik masyarakat yang berada di dalam kawasan Hutan Lindung Sungai Wain maupun masyarakat yang di luar kawasan Hutan Lindung Sungai Wain.

Sikap Masyarakat Terhadap Cara-cara Pembukaan Lahan

Pada masyarakat lokal seperti di Kelurahan Karang Joang, budaya membuka lahan dengan merintis/menebas lalu membakar untuk mempercepat proses penyiapan lahan tersebut telah dilakukan sejak lama, secara turun temurun hingga sekarang masih terus berlangsung. Secara alami mereka telah memiliki pengetahuan teknis yang disebut kearifan lokal, tanpa disadari mereka telah melakukannya seperti membuat sekat bakar berupa rintisan-rintisan disekitar ladang/kebun yang terlihat seperti jalan atau parit, dan juga membuat sekat hijau berupa penanaman pohon buah-buahan lokal (durian, lay, mangga, rambutan dan sebagainya).

Masyarakat umumnya mengetahui bahwa penyiapan lahan dengan membakar mengakibatkan tingkat kesuburan tanah berkurang, karena itulah mereka melakukan kegiatan berladang berpindah yang dimaksudkan untuk memulihkan kondisi tanah untuk jangka waktu tertentu. Penyiapan lahan kebun dengan cara dibakar antara lain dimaksudkan untuk membersihkan lahan tanaman dalam waktu secepatnya dan dengan tidak menggunakan tenaga kerja terlalu banyak, disamping itu untuk mengurangi intensitas serangan hama dan penyakit yang bersumber dari dalam dan permukaan tanah. Secara lengkap sikap responden terhadap aspek budaya masyarakat Kelurahan Karang Joang dalam pola penyiapan lahan disajikan dalam tabel di bawah ini.

Tabel 1. Sikap Responden Terhadap Aspek Budaya Masyarakat Kelurahan Karang Joang Dalam Pola Penyiapan Lahani

\begin{tabular}{|c|c|c|c|}
\hline \multirow[b]{2}{*}{ Kegiatan } & \multicolumn{2}{|c|}{ Sikap Responden } & \multirow[b]{2}{*}{$\begin{array}{l}\text { Tidak Pernah } \\
(\%)\end{array}$} \\
\hline & $\begin{array}{l}\text { Selalu } \\
(\%)\end{array}$ & $\begin{array}{l}\text { Kadang-kadang } \\
(\%)\end{array}$ & \\
\hline $\begin{array}{l}\text { 1. Membuka ladang/kebun di hutan dalam } \\
\text { penyiapan lahan dengan diawali membakar } \\
\text { hutan }\end{array}$ & 62,5 & 37,5 & \\
\hline $\begin{array}{l}\text { 2. Membuat Sekat Bakar dalam penyiapan } \\
\text { lahan dengan membakar }\end{array}$ & 75,0 & 25,0 & \\
\hline $\begin{array}{l}\text { 3. Menjaga/mengawasi pada saat membakar } \\
\text { untuk penyiapan lahan }\end{array}$ & 75,0 & 25,0 & \\
\hline $\begin{array}{l}\text { 4. Mempersiapkan daerah aman dan potensi } \\
\text { lain (seperti sumber air/sumur, tanki air,dsb) } \\
\text { yang dapat dijadikan bahan untuk } \\
\text { pemadaman apabila kebakaran membesar } \\
\text { tidak sesuai rencana }\end{array}$ & 25,0 & 50,0 & 25,0 \\
\hline $\begin{array}{l}\text { 5. Dalam membakar sesuai dengan luas areal } \\
\text { yang diinginkan }\end{array}$ & 62,5 & 37,5 & \\
\hline $\begin{array}{l}\text { 6. Melakukan kegiatan pertanian sesuai dengan } \\
\text { kalender musim }\end{array}$ & 37,5 & 37,5 & 25,0 \\
\hline
\end{tabular}

Dari Tabel 1 terlihat bahwa masyarakat yang melakukan kegiatan pembakaran lebih dari 62,50\%. Masyarakat Karang Joang melakukan kegiatan membakar dalam penyiapan lahan untuk ladang/kebun. Dan lebih dari 37,50\% kadang-kadang melakukan kegiatan pembakaran dalam penyiapan lahan karena lebih berkonsentrasi pada perkebunan karet yang memerlukan waktu panjang dengan hasil yang cukup baik bagi peningkatan pendapatan keluarga sehingga kegiatan pertanian seperti penanaman padi hanya dilakukan kadang-kadang hanya untuk pemenuhan kebutuhan pokok keluarga saja. Masyarakat Kelurahan Karang Joang mengetahui pentingnya membuat sekat bakar yaitu dengan membuat rintisan-rintisan di sekitar ladang/kebun yang terlihat seperti 
jalan atau parit, dan juga membuat sekat hijau berupa penanaman pohon buah-buahan lokal (durian, lay, mangga, rambutan, dan sebagainya). Kondisi bahan bakar berupa pohon semak dan pada umumnya basah karena curah hujan bulanan yang cukup tinggi sehingga memerlukan waktu pembakaran dua kali atau bahkan lebih.

\subsection{Sebab-sebab Terjadinya Kebakaran}

Interaksi antara kelompok masyarakat dapat disebut sebagai interaksi sosial yang berpengaruh dalam tatanan kehidupan masyarakat sehari-hari. Adanya budaya gotong royong sebagai ciri khas bangsa Indonesia yang hidup sebagai makhluk sosial. Penyebab kebakaran hutan menurut pengetahuan responden dari masyarakat Kelurahan Karang Joang dapat dilihat pada Tabel di bawah ini.

Tabel 2. Penyebab Kebakaran Hutan dan Lahan di Kelurahan Karang Joang

\begin{tabular}{ll}
\hline Penyebab & Prosentase (\%) \\
\hline a. Penyiapan ladang / kebun & 25,0 \\
b. Batubara & 12,5 \\
c. Kelalaian & 62,5 \\
d. Kesengajaan / Konflik & - \\
e. Lain-lain & - \\
\hline Jumlah & 100,0 \\
\hline
\end{tabular}

Menurut sebagian besar responden penyebab kebakaran hutan dan lahan terbesar di wilayah Kelurahan Karang Joang adalah diakibatkan oleh kelalaian masyarakat yaitu sebesar 62,5\%. Kebakaran dapat terjadi karena perbuatan yang tidak disengaja dan kurang disadari seperti pembuangan puntung rokok, membakar sampah sisa-sisa tumbuhan disembarang tempat dan tidak terkontrol dan lain sebagainya.

Maraknya aktivitas penambangan batu bara akhir-akhir ini ternyata juga menjadi penyumbang terjadinya kebakaran hutan dan lahan di wilayah Kelurahan Karangb Joang, seperti diketauhi batu bara merupakan sumber panas yang timbul secara alami khususnya pada musim-musim kemarau. Kebakaran hutan dan lahan yang disebabkan oleh akumulasi panas batubara di Kelurahan Karang Joang cukup besar yaitu sebesar 12,5\%. Menurut perkiraan atau asumsi peneliti selama ini, penyebab kabaran hutan dan lahan terbesar diakibatkan oleh kegiatan pembukaan/penyiapan lahan atau kebun, tapi ternyata oleh sebab lain diluar kegiatan ini, dan hanya sebanyak $25 \%$ responden yang menyatakan bahwa penyebab kebakaran adalah dari aktivitas penyiapan lahan tanam.

\subsection{Sikap Masyarakat Terhadap} Sosialisasi Upaya-upaya Pencegahan Kebakaran Hutan dan Lahan Oleh Pemerintahi

Pada dasarnya kejadian kebakaran tidak hanya di dalam kawasan hutan, tetapi juga terjadi di kawasan selain hutan, baik perkebunan maupun ladang dan lahan pertanian masyarakat yang justru mencapai kondisi yang cukup luas sehingga perlu mendapat perhatian yang serius dari semua pihak, bahkan menurut pendapat sebagian masyarakat kadangkadang kebakaran lahan dan kebun menjadi sebab terjadinya kebakaran hutan yang ada disekitarnya.

Oleh karena itu pelibatan berbagai pihak khususnya masyarakat desa disekitar hutan dalam kegiatan pencegahan dan penanggulangan kebakaran hutan menjadi penting dan perlu. Pemerintah telah melakukan berbagai sosialisasi dan pemberian bantuan atau dengan istilah insentif untuk pembentukan organisasi masyarakat didesa-desa seperti pemberian bantuan peralatan dan berbagai dukungan dalam 
pembentukan regu-regu pemadaman kebakaran hutan dan lahan (Hidayah, 1998), dan (Rahardjo. 1999).

Dalam sistem penanggulangan kebakaran hutan yang dapat diimplementasikan kepada masyarakat bahwa unsur manajemen dalam pengendalian kebakaran yang berperan dalam penerapannya di lapangan. Dalam penelitian ini penulis melakukan wawancara dan pengisian kuesioner untuk memeperoleh data mengenai kegiatan sosialisasi dan upaya-upaya pemerintah melibatkan masyarakat dalam kegiatan penanggulangan kebakaran hutan dan lahan. Rekapitulasi hasil wawancara kepada responden yang mengetahui atau pernah mengikuti kegiatan sosialisasi dan pembentukan yang dilakukan di Kelurahan Karang Joang dapat dilihat pada Tabel di bawah ini :

Tabel 3. Upaya Pemerintah Sosialisasi Kebakaran Hutan

\begin{tabular}{ll}
\hline Bentuk Upaya Pemerintah & Prosentase (\%) \\
\hline a. Kegiatan Penyuluhan & 84,0 \\
b. Pembentukan regu pemadam & 44,0 \\
c. Pemberian Kelengkapan Peralatan & 44,0 \\
d. Lain-lain & - \\
\hline
\end{tabular}

Berdasarkan data yang diperoleh dari hasil wawancara dan pengisian kuisioner ternyata antusiasme masyarakat Kelurahan Karang Joang dalam mendukung upayaupaya pemerintah dalam penanggulangan kebakaran hutan dan lahan cukup besar, dari rekapitulasi data pada Tabel di atas terlihat bahwa 44 orang responden atau sebesar $84,0 \%$ mengetahui dan pernah mengikuti kegiatan penyuluhan mengenai usaha-usaha pelibatan masyarakat dalam kegiatan penanggulangan kebakaran hutan dan lahan. Selanjutnya dalam pembentukan regu pemadaman kebakaran hutan dan lahan, sebanyak 22 orang atau $44,0 \%$ menyatakan mengetahui adanya regu pemadaman kebakaran yang pernah dibentuk, dan sebanyak 22 orang $(44,0)$ juga menyatakan bahwa kepada regu-regu pemadaman kebakaran hutan dan lahan pernah diberikan insentif berupa pemberian peralatan untuk mendukung kegiatan pemadaman kebakaran.

\section{KESIMPULAN}

Berdasarkan latar belakang, tujuan, perumusan masalah serta hasil dari pembahasan yang telah diuraikan terdahulu, maka dapat diperoleh gambaran untuk ditarik beberapa kesimpulan : 1) Sistem penanggulangan kebakaran hutan berbasis masyarakat telah dilaksanakan secara turun temurun oleh masyarakat dengan menggunakan teknik dan peralatan tradisional. Dalam penyiapan lahan, masyarakat lokal masih melakukan pembakaran, dan selalu membuat sekat bakar berupa rintisanrintisan di sekeliling areal yang akan dibakar serta melakukan pengawasan pada saat membakar untuk menghindari perluasan api. 
2) Strategi dalam penanggulangan kebakaran hutan dan lahan berbasis masyarakat adalah peningkatan taraf pendidikan masyarakat, meminimalkan sistem perladangan berpindah (gilir balik) dengan pola tebas bakar dan mencari sumber dana secara mandiri untuk meminimalkan terjadinya bahaya kebakaran yang menyebabkan bertambah luasnya lahan kritis dan perlu rehabilitasi lahan, konflik kepemilikan lahan, dan keterbatasan tenaga pendamping. 3) Rancangan alternatif dalam pengembangan sistem PKHBM adalah upaya-upaya pencegahan dan penanggulangan secara teknis, penerapan pola tanam terpadu, pendekatan partisipatif dalam penyusunan program PKHBM, serta pembentukan usaha kelompok bersama (UKB) dan pendampingan intensif.

\section{DAFTAR PUSTAKA}

Anonim. 2002. Bahan Bacaan Pembinaan Masyarakat Dan Sosialisasi Pengendalian Kebakaran Hutan Dan Lahan. UPTD Pengendalian Kebakaran Hutan dan Lahan. Dinas Kehutanan Propinsi Kalimantan Timur. Samarinda.
Hidayah, AK. 1998. Keterlibatan Masyarakat Lokal Sebagai Tenaga Kerja HPH Pada PT. Bukit Baiduri Enterprise Limbang Ganeca Di Kalimantan Timur. Tesis Pasca Sarjana Magister Ilmu Kehutanan UNMUL. Samarinda (tidak diterbitkan).

Hoffman, A. A., A. Heinrichs and F. Siegert. 1999. Fire Damage in East Kalimantan in 1997/1998 related to Land Use and Vegetation Classes : Satellite Radar Inventory Result and Proposal for further Action. IFFM-SFMP Report No. 1a and b, Samarinda (Eng \& Ind).

Rahardjo. 1999. Pengantar Sosiologi Pedesaan dan Pertanian. Gadjah Mada University Press. Yogyakarta.

Singarimbun, M. 1989. Metode Dan Prosedur Penelitian. Dalam Singarimbun, M dan Effendi, S. (Edisi Kedua) 1989. Metode Penelitian. LP3. Jakarta. 
Tambunan, Hendry M. 2003.

Keterlibatan Masyarakat Di Dalam Proyek Penghijauan DAK-DR Di Desa Bhuana Jaya Kecamatan Tenggarong Seberang Kabupaten
Kutai Kartanegara. Skripsi Sarjana Kehutanan Fakultas Pertanian Universitas 17 Agustus 1945. Samarinda (tidak diterbitkan). 